\title{
FACTORS INFLUENCING LEARNERS' SELF-REGULATED LEARNING SKILLS IN A MASSIVE OPEN ONLINE COURSE (MOOC) ENVIRONMENT
}

\author{
Nour Awni ALBELBISI \\ ORCID: 0000-0002-7800-6483 \\ Faculty of Education, University of Malaya \\ Kuala Lumpur, Malaysia \\ Dr. Farrah Dina YUSOP \\ ORCID: 0000-0002-5796-4463 \\ Faculty of Education, University of Malaya \\ Kuala Lumpur, Malaysia
}

Received: 15/12/2018 Accepted: 21/01/2019

\begin{abstract}
The importance of self-regulation in a MOOC has been extensively discussed in research studies that provide evidence about the significant relationship between self-regulated learning and success in an e-learning environment. Learners with high self-regulated learning are more independent in regulating their learning and have a greater probability of success in their online courses. This study identifies factors that influence self-regulated learning and determines relationships between these factors and self-regulated learning. A conceptual model is proposed for combining success factors for self-regulated learning in a MOOC environment. A research instrument based on the model was designed and administered to six hundred and twenty-two MOOC students enrolled in five universities. Relationships between relevant factors and selfregulated learning were examined using a Partial Least Squares Structural Equation Modeling (PLS-SEM) technique, and the statistical findings revealed that three factors - service quality, attitude, and course quality - influence self-regulated learning in a MOOC.
\end{abstract}

Keywords: MOOC, Massive Open Online Courses, self-regulated learning, MOOC success.

\section{INTRODUCTION}

A Massive Open Online Course (MOOC) is a new phenomenon in e-learning sector that has substantial capability to provide free online courses to a huge group of learners around the world. MOOC contributes to improvement of educational institutions (Mazoue, 2014) by allowing learners to effectively exchange knowledge and experience through collaborative learning. MOOC offers several features such as interaction, self-reflection, collaboration, and evaluation that support learning experiences (de Waard et al., 2014).

Despite the growth in MOOC implementation, there are some issues surrounding its successful implementation in higher education contexts; one such issue is the high dropout rate among MOOC learners (Parr, 2013). Research studies (e.g. Alraimi, Zo, \& Ciganek, 2015; Hew \& Cheung, 2014) have indicated that completion rates in MOOC courses could be less than 10\%, and such high dropout rates have occurred across multiple institutions. The Massachusetts Institute of Technology (MIT), for example, established its first MOOC in 2012 with a total of 155,000 students enrolled, experienced a dropout rate of more than $95 \%$, meaning that only 7,000 out of 155,000 students successfully completed the course (Daniel \& Uvalic-Trumbic, 2013). Such a high dropout rate obviously reflects an unsuccessful implementation of $\mathrm{MOOC}$ at the institutional level.

Since the literature strongly indicates that the high dropout rate in online learning courses may be due to a mix of factors associated with courses, services, and educational quality (Alsabawy, Cater-Steel, \& Soar, 2012), understanding the factors that affect MOOC success is critical and careful consideration of these factors could help improve the effectiveness of implementing MOOC and diminish its failings (Alsabawy et al., 2012; Authors, 2018), especially for MOOC stakeholders, administrators, managers and scholars (Alsabawy, CaterSteel, \& Soar, 2011). 
Current MOOC literature has described the important role of learners' self-regulated learning (SRL) skills in accomplishing MOOC success (e.g. Hood, Littlejohn, \& Milligan, 2015; Littlejohn \& Milligan, 2015; Terras \& Ramsay, 2015). MOOC provides learners with powerful self-regulated learning skills (i.e., time management and effort regulation) to promote learning, particularly self-directed learning (Kizilcec, Pérez-Sanagustín, \& Maldonado, 2016; Magen-Nagar \& Cohen, 2016). This leads to a high degree of selfregulation that in turn leads to greater engagement within learning via MOOC and makes students more likely to succeed in their learning (Kizilcec, Pérez-Sanagustín, \& Maldonado, 2017; Liaw \& Huang, 2013).

Adopting from the DeLone \& McLean Information System model (2003), this study extends the current literature by examining five (5) major factors that influence learners' SRL skills. The five factors are: (1) system quality; (2) information quality; (3) service quality; (4) attitude; and (5) course quality. Understanding the influence of each of these factors is important to support building a successful operational framework of MOOC success factors.

\section{AIM OF THE STUDY}

This study aims to combine the MOOC success factors for self-regulated learning in a proposed model based on the D \& M (2003) model, and to identify the relationships between these factors and SRL. It also seeks to offer interested researchers scientific results related to self-regulated learning skills in MOOC environments. Within this perspective, the research objectives for this study are as follows:

1. To determine the key factors that influence self-regulated learning in MOOC; and

2. To determine the relationships between the factors in the proposed model.

This study has been guided by the following research questions:

1. What are the key factors influencing self-regulated learning in MOOC?

2. What are the relationships between 5 success factors (i.e. system quality, information quality, service quality, student attitude, course quality) and learners' self-regulated learning?

\section{SIGNIFICANCE OF THE STUDY}

This study intends to contribute to a better understanding of MOOC literature by highlighting the factors influencing self-regulated learning and combining them into a framework based on the D \& M (2003) model to guide researchers, educators, and instructional designers to develop effective MOOC environments that can effectively support learners self-regulated learning skills and subsequent success in MOOC.

\section{LITERATURE REVIEW}

\section{Self-Regulated Learning}

The concept of self-regulated learning relates to how individuals manage their personal learning processes, especially how to monitor, regulate, and evaluate their own learning, and plan learning actions and behavioral processes that increase likelihood of goal attainment (Zimmerman, 2015).

Self-regulated learning has received great attention in the online learning literature (Cho \& Kim, 2013; Terras \& Ramsay, 2015; Zhao, 2016). In these studies, the vital role of self-regulated learning with respect to learner behavior online was highlighted, and the influence of self-regulation on promoting success in online learning environments was revealed (Cho \& Kim, 2013; Terras \& Ramsay, 2015). Student success in e-learning clearly requires effective use of self-regulated learning strategies (Barnard-Brak, Paton, \& Lan, 2010).

Cho and Shen (2013) examined the role of self-regulation skills and found that since learners with a high level of self-regulation are more independent learners in regulating their learning thus, their probability of success in online courses is greater. Self-regulation skills contribute to supporting learners' engagement and improve learning strategies achieved through instructional interventions and practice in implementing the self-regulated learning process. Self-regulated learning skills can enhance learners' ability to regularly 
review their material, to effectively manage their time, to seek assistance from peers or instructors, and to provide the required metacognition skills that reflect their own learning (You \& Kang, 2014). Self-regulated learning (SRL) contributes to develop learners' skills related to being active learners in obtaining the required knowledge and improving their personal steps toward mastering that knowledge. Enhanced self-regulated learning skills help learners to find the best solutions for challenges or obstacles facing them, thus achieving their learning goals and succeeding in their learning process. Broadbent and Poon (2015) indicated that highly self-regulated learners exhibit effective positive motivation and self-efficiency with respect to their own learning processes through such activities as selecting learning content, identifying learning goals, and organizing and controlling their learning processes.

Conversely, not all students have the motivation required to organize their online course activity, and not all of them are able to effectively regulate their online learning. Many studies have identified the lack of SRL skills among participants involved in online learning settings (Kizilcec \& Halawa, 2015; Lee, Choi, \& Kim, 2012; Nawrot \& Doucet, 2014). For instance, Lee et al. (2012) argue that students without the ability to manage their own online learning will face difficulties and this may hinder their success in online courses. The literature indicates that learners with low self-regulation skills would be less likely to achieve success in the e-learning field (Cho \& Shen, 2013; Kizilcec \& Halawa, 2015). You and Kang (2014) highlighted that lack of self-regulation skills in e-learning environments may result in learners consuming extra time in completing the assignments, causing turning in late assignments or generally poor-quality work. Nawrot and Doucet (2014) also indicated that lesser student experience with regulating their own learning (such as poor time management) can lead to increase in course withdrawal, frustration, and consequently poor academic outcomes.

\section{MOOC and Self-Regulated Learning}

MOOC is a platform for communication and collaboration in which participants exchange information to enhance their knowledge (de Waard et al., 2014). Many MOOCs have been designed to encourage learners to regulate their learning all by themselves rather than depending on instructor guidance. Since MOOC learners can independently select learning resources and choose to participate in activities (Davis, Chen, Jivet, Hauff, \& Houben, 2016), they may require learners to regulate their learning while using MOOC. Previous research suggests that MOOC learners with highly self-regulated learning exhibit different cognitive, affective, and behavioral reactions toward learning in MOOC than those who exhibit lower levels of selfregulated learning (Hood et al., 2015; Littlejohn \& Milligan, 2015). It is clear that MOOC success requires high levels of self-regulated learning (SRL) skills, but at present not much research is available on how to support self-regulated learning skills in a MOOC environment (Onah \& Sinclair, 2017).

There is also growing evidence that MOOC has significant potential to support student self-regulated learning (Littlejohn, Hood, Milligan, \& Mustain, 2016). Since MOOC learners must be independent and active participants in the learning process, those with higher self-regulated learning skills exhibit more ability to engage in learning by individually setting learning objectives, identifying the effective learning techniques, and monitoring the processes of achieving their objectives (Kizilcec et al., 2016). Unfortunately, many groups of MOOC learners continue to struggle with self-regulating their learning (Milligan, Littlejohn, \& Margaryan, 2013). Consequently, because of the importance of SRL skill in MOOC system success and the rarity of available studies about the relationships between MOOC and student self-regulated learning, this study examines SRL as a dependent factor and investigates the factors that influence SRL in a MOOC environment.

\section{THEORETICAL FRAMEWORK}

\section{DeLone and McLean Model}

The DeLone and McLean model is considered one of the most important models contributed to assessment of e-learning systems success (Alsabawy et al., 2011). The model hypothesizes that factors of information quality, system quality, and service quality all have positive influence on user satisfaction and use/intention to use particular systems. Figure 1 the displays DeLone and McLean (2003) model. 


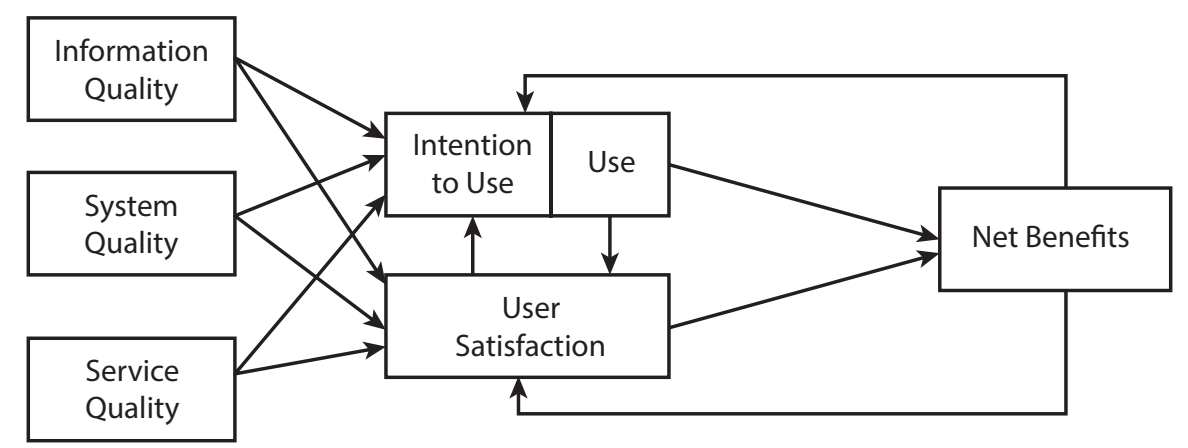

Figure 1. DeLone \& McLean (2003) model.

System quality relates to how well the hardware and the software work together; in other words, it refers to the effectiveness of processing system information (DeLone \& McLean, 2003). Information quality is related to measurement of the quality of information created by a system (Petter, DeLone \& McLean, 2008) while service quality refers to the level and manner in which services are provided by the information system sector or system providers (DeLone \& McLean, 2003).

Many studies (e.g., Freeze, Alshare, Lane, \& Wen, 2010; Hassanzadeh, Kanaani, \& Elahi, 2012; Tella, 2011; Wang \& Chiu, 2011) have tested the validity of DeLone and McLean's model. Some of these studies adopted DeLone and McLean's model in its entirety while others partially tested the model by examining some of its specific factors. Some studies, on the other hand, extended the DeLone and McLean model by including other external factors to achieve deeper understanding of system success.

Because of the vital role of self-regulated learning skills in e-learning environments, many studies have indicated that a self-regulated learning factor should be considered as a principal dimension in evaluating systems success, so Lee and Lee (2008) modified the D \& M model by adding self-regulated learning as a moderating variable. Zhao (2016) also proposed a new learning system success model in the particular context of e-learning 2.0. This model reframes the original $\mathrm{D} \& \mathrm{M}$ model by adding communication quality and replacing net benefit with self-regulation as dependent variables, as shown in Figure 2.

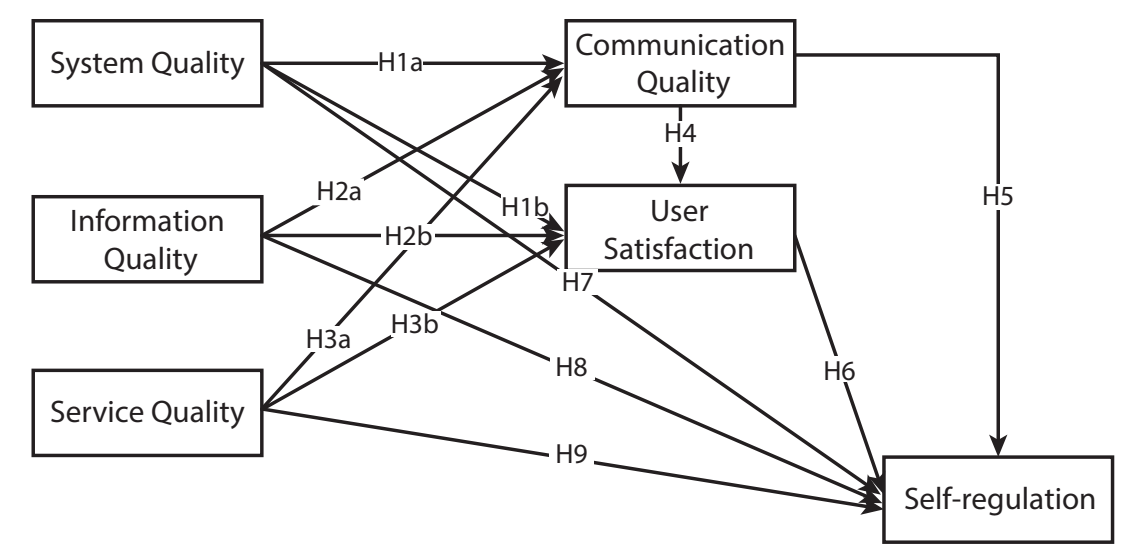

Figure 2. Modification of DeLone \& McLean (2003) model by Zhao (2016).

\section{Research Model and Hypotheses}

Samarasinghe (2012) indicated that there are insufficient dimensions in the D\&M (2003) model to measure system success and cover all of the relevant e-learning success features, so he recommended inclusion of other significant factors related to both learners and courses in the model.

This study therefore proposes a model that includes a total of six variables: information quality, system quality, service quality, course quality, attitude, and self-regulated learning. Arrows can be used to denote proposed relationships among the six variables in the research model as shown in Figure 3. 


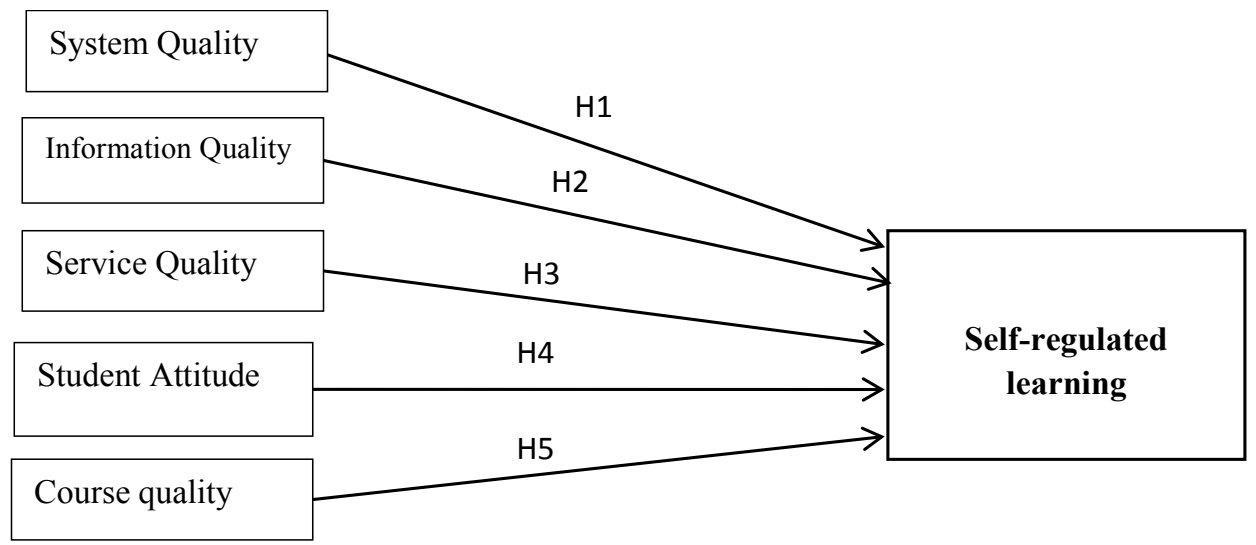

Figure 3. Research model

In this model, system quality refers to the degree to which learners perceive that a MOOC system is easy to use, easy to learn, has integrity, and is reliable. The second factor in this study, information quality, represents the quality and relevance of the information offered by MOOC systems. In other words, information quality refers to the ability of a MOOC to provide information that exactly meets learners' needs, is relevant to learners' job, is easy to understand, and is up to date. On the other hand, attitude refers to the set of learner beliefs in using MOOC regarding whether it is good or bad. Finally, course quality in this study refers the extent to which a learner believes that a MOOC offers quality content.

\section{Hypotheses}

Barnard-Brak et al., (2010) defined self-regulated learning as voluntary behavior of an individual to measure his or her own success in learning. MOOC can enable learners to individually regulate their learning processes by promoting self-reflection, developing learning objectives, planning time use effectively, and managing skills (Onah \& Sinclair, 2017). Some researchers (e.g., Littlejohn et al., 2016) have also discussed MOOC used to promote self-regulation skills. Learners with high self-regulation levels contribute to engagement within e-learning and are more likely to succeed in e-learning environments (Liaw \& Huang, 2013; Zhao, 2016).

In a related study, Zhao (2016) examined factors influencing self-regulation skill in an online learning environment such as MOOC and revealed the three (3) main factors related to system success: system quality, information quality, and service quality. The following hypotheses are therefore proposed:

H1: There is a positive relationship between system quality and learners' self-regulated learning in MOOC environment.

H2: There is a positive relationship between information quality and learners' self-regulated learning in MOOC environment.

H3: There is a positive relationship between service quality and learners' self-regulated learning in MOOC environment.

Since many studies have shown that self-regulation is a critical factor affecting student attitudes toward e-learning (Kramarski \& Gutman, 2006; Zimmerman \& Schunk, 2001), H4 is also proposed.

H4: There is a positive relationship between attitude and learners' self-regulated learning in MOOC environment.

Lin, Lin, and Hung (2015) argue that the perceptions of learners toward the quality and richness of course content have significant influence with respect to accepting the knowledge provided. Rai and Chunrao (2016) noted the role of quality of course in MOOC systems success. Therefore, H5 is proposed.

H5: There is a positive relationship between course quality and learners' self-regulated learning in MOOC environment. 


\section{METHODOLOGY}

\section{Research Instrument}

The questionnaire used in this research was gleaned and compiled various validated instruments from the literature reviewed on e-learning and MOOC but some modifications were made to wording to suit the context of this research. System quality and information quality factors were measured with a scale developed by Alsabawy et al. (2012) while service quality was measured by a scale developed by Ozkan, Koseler, and Baykal (2009). Course quality items were adapted from a study by Rhema and Miliszewska (2014) whilst self-regulated learning factor was examined by a scale for Onah and Sinclair (2017). Most of these studies employed the D \& M (2003) model in their researches.

The research instrument is divided into two parts. Part 1 includes demographic information, including gender, age, and previous experience with MOOC, while the second part includes measurement items of the research model based on six constructs: system quality, information quality, service quality, attitude, course quality, and self-regulated learning. The questionnaire covered 41 items using a 5-point Likert scale ranging from "Strongly agree (5)," to "Strongly disagree (1)".

\section{Data Collection and Analysis}

The questionnaire was administered to 1000 undergraduate students from the top active MOOC user universities in Malaysia. All participants had been enrolled in at least one MOOC course via the OpenLearning platform, the official MOOC platform in Malaysia.

From the total number of 1000 questionnaires administered, 622 valid questionnaires were returned, an effective response rate of $62.2 \%$. In the final sample population, $63.8 \%$ participants were females and $35.9 \%$ were males. The majority of the participants, $54.2 \%$, were of ages between 20 and 30 years. With regard to participants' experience in MOOC, $41.3 \%$ of the participants had limited experience with a current MOOC course.

Data from the questionnaires were analyzed using the Partial Least Squares Structural Equation Modeling (PLS-SEM) technique (Ringle, Wende, \& Becker, 2015) because PLS-SEM enables researchers to acquire an accurate study model and is considered suitable for testing new models (Henseler, Ringle, \& Sinkovics, 2009).

\section{Reliability and Validity of the Proposed Model}

The reliability of the questionnaire was measured using Cronbach's alpha ( $\alpha$ ), the most common indicator for internal consistency, an $\alpha$ value greater than 0.70 indicating good reliability (Hair et al., 2006). The data analysis revealed that the Cronbach's alpha for the items in the questionnaire was between 0.70 and 0.915 , reflecting its high reliability.

Analysis of validity was then conducted using PLS-SEM analysis. Validity refers to the capability of the measurement items to effectively measure the intended constructs (Hair, Black, Babin, \& Anderson, 2010). In this study, validity was measured in two stages: (1) analysis of the measurement model, and (2) analysis of the structural model (Hair, Ringle, \& Sarstedt, 2011). The findings of these analyses are presented in the next section.

\section{FINDINGS}

\section{Analysis of the Measurement Model}

In the first stage, analysis of the measurement model was conducted by evaluating convergent and discriminant validity. Three indices were used to test convergent validity. First, by assessing factor loading, each item loading of the construct should be greater than 0.50 to achieve convergent validity (Hair et al., 2006). Second, the value of Average Variance Extracted (AVE) that should exceed 0.50 was tested. Third, the value of composite reliability (CR) of each item, that should be greater than 0.7 , was examined (Hair, Hult, Ringle, \& Sarstedt, 2014). The results of convergent validity determination for the questionnaire items are displayed in Table 1. 
Table 1 . The convergent validity results

\begin{tabular}{|c|c|c|c|c|c|}
\hline Construct & Items & Measurement variables & Loading & SCR & AVE \\
\hline & AT1 & I feel confident in using MOOC. & 0.800 & 0.934 & 0.639 \\
\hline & AT2 & I enjoy using MOOC for my studies. & 0.818 & & \\
\hline & AT3 & I believe that MOOC gives me the opportunity to acquire new knowledge. & 0.778 & & \\
\hline & AT4 & I believe that MOOC enhances my learning experience. & 0.817 & & \\
\hline Attitude & AT5 & I believe that convenience is an important feature of $\mathrm{MOOC}$. & 0.760 & & \\
\hline & AT6 & $\begin{array}{l}\text { I believe that MOOC increases the quality of learning because it integrates all } \\
\text { forms of media. }\end{array}$ & 0.775 & & \\
\hline & AT7 & I believe that adopting MOOC allows for increased student satisfaction. & 0.797 & & \\
\hline & AT8 & I believe that studying courses that use MOOC is interesting. & 0.812 & & \\
\hline & AT9 & In my MOOC learning experiences, the courses content is up-to-date. & 0.641 & & \\
\hline & CQ1 & $\begin{array}{l}\text { In my MOOC learning experiences, learning outcomes for the course are } \\
\text { summarized in clearly written, straightforward statements. }\end{array}$ & 0.791 & 0.863 & 0.678 \\
\hline $\begin{array}{l}\text { Course } \\
\text { quality }\end{array}$ & CQ2 & $\begin{array}{l}\text { In my MOOC learning experiences, courses are designed to encourage } \\
\text { learners to work together utilizing problem-solving activities to develop topic } \\
\text { understanding. }\end{array}$ & 0.833 & & \\
\hline & CQ3 & In my MOOC learning experiences, the course content is communicated well. & 0.846 & & \\
\hline & IQ1 & I believe that MOOC system provides me with the outputs that I need. & 0.783 & 0.881 & 0.649 \\
\hline Information & IQ2 & $\begin{array}{l}\text { I believe that information (i.e. learning materials) from the MOOC system is in a } \\
\text { form that is readily usable. }\end{array}$ & 0.822 & & \\
\hline & IQ3 & $\begin{array}{l}\text { I believe that, } M O O C \text { system provides information (i.e. learning materials) that is } \\
\text { easy to understand. }\end{array}$ & 0.809 & & \\
\hline & IQ4 & $\begin{array}{l}\text { I believe that information (i.e. learning materials) from the MOOC system is } \\
\text { concise. }\end{array}$ & 0.808 & & \\
\hline & SQ1 & For me, the MOOC system is easy to use. & 0.799 & 0.894 & 0.629 \\
\hline System & SQ2 & For me, the MOOC system is easy to manage. & 0.806 & & \\
\hline & SQ3 & For me, MOOC system meets my expectations. & 0.840 & & \\
\hline & SQ4 & For me, MOOC system includes necessary features and functions for my study. & 0.812 & & \\
\hline & SQ5 & For me, all data within MOOC system is fully integrated and consistent. & 0.701 & & \\
\hline & SRQ1 & In my MOOC learning experiences, the instructors are good to learners. & 0.844 & 0.875 & 0.639 \\
\hline & SRQ2 & In my MOOC learning experiences, the instructors are friendly to learners. & 0.841 & & \\
\hline quality & $\mathrm{SRQ3}$ & $\begin{array}{l}\text { In my MOOC learning experiences, the instructors are knowledgeable enough } \\
\text { about the content. }\end{array}$ & 0.807 & & \\
\hline & SRQ4 & $\begin{array}{l}\text { In my MOOC learning experiences, the instructors are available via e-mail, } \\
\text { phone or fax. }\end{array}$ & 0.696 & & \\
\hline & SR1 & I know what I am going to achieve in this MOOC course. & 0.712 & 0.914 & 0.57 \\
\hline & SR2 & I have set aside time to study the MOOC course. & 0.727 & & \\
\hline & SR3 & I have high standards for my work on this MOOC course. & 0.788 & & \\
\hline & SR4 & I have set targets for all I want to achieve in this MOOC course. & 0.772 & & \\
\hline & SR5 & I have written down the goals I plan to achieve by the end of this $\mathrm{MOOC}$ course. & 0.744 & & \\
\hline & SR6 & $\begin{array}{l}\text { I work strategically to prioritize tasks to help me achieve my learning goals in } \\
\text { MOOC course. }\end{array}$ & 0.773 & & \\
\hline & SR7 & $\begin{array}{l}\text { I am prepared to tackle any challenging aspects of the work in this } \mathrm{MOOC} \\
\text { course. }\end{array}$ & 0.738 & & \\
\hline $\begin{array}{l}\text { Self- } \\
\text { Regulated }\end{array}$ & SR8 & $\begin{array}{l}\text { I have planned ahead in order to devote the necessary time to my online } \\
\text { studies. }\end{array}$ & 0.782 & & \\
\hline & SR9 & I find a good time to study when I won't be distracted. & 0.774 & & \\
\hline & SR10 & I choose my study location in order to avoid distractions. & 0.824 & & \\
\hline & SR11 & I find a comfortable place to study. & 0.851 & & \\
\hline & SR12 & I choose an appropriate place to work in order to study effectively. & 0.793 & & \\
\hline & SR13 & $\begin{array}{l}\text { I plan to use the interactive communication channels provided to gain support } \\
\text { from peers and tutors. }\end{array}$ & 0.760 & & \\
\hline & SR14 & $\begin{array}{l}\text { I plan to participate in the course discussion forums in order to get the most out } \\
\text { of the course. }\end{array}$ & 0.813 & & \\
\hline & SR15 & While engaging in this course, I will reflect on my study in each module. & 0.849 & & \\
\hline & SR16 & $\begin{array}{l}\text { I will be proactive in engaging and reviewing progress in the learning path I } \\
\text { select. }\end{array}$ & 0.808 & & \\
\hline
\end{tabular}


As shown in Table 1, the factor loadings for all factors were all higher than 0.6., and the AVE values were also above 0.5 . The composite reliability (CR) for the factors were 0.8 and higher, suggesting good convergent validity.

Next, the discriminant validity of the model factors was established. Discriminant validity is the degree to which measurement items of a specific factor reflect that factor instead of other factors in the same model (Hulland, 1999). In this study, the new HTMT criteria using PLS was conducted to check for lack of discriminant validity. HTMT discriminant validity between two constructs is established when the HTMT 0.85 value is less than 0.85 (Kline, 2011), or HTMT 0.90 value is less than 0.90 (Gold, Malhotra, \& Segars, 2001) when the confidence interval has a value of one (Henseler, Ringle, \& Sarstedt, 2015). The HeterotraitMonotrait (HTMT) Analysis is shown in Table 2.

Table 2. The Heterotrait-Monotrait (HTMT) Analysis

\begin{tabular}{|c|c|c|c|c|c|c|}
\hline & AT & $\mathbf{C Q}$ & $\mathbf{I Q}$ & SRL & SRQ & $S Q$ \\
\hline AT & & & & & & \\
\hline $\mathbf{C Q}$ & $\begin{array}{c}0.836 \\
\text { Cl.90 }(0.786,0.883)\end{array}$ & & & & & \\
\hline IQ & $\begin{array}{c}0.800 \\
\text { Cl.90 }(0.748,0.894)\end{array}$ & $\begin{array}{c}0.796 \\
\text { Cl.90 }(0.724,0.862)\end{array}$ & & & & \\
\hline SRL & $\begin{array}{c}0.715 \\
\text { Cl.90 }(0.662,0.770)\end{array}$ & $\begin{array}{c}0.758 \\
\text { Cl.90 }(0.693,0.821)\end{array}$ & $\begin{array}{c}0.651 \\
\text { Cl.90 }(0.575,0.717)\end{array}$ & & & \\
\hline SRQ & $\begin{array}{c}0.650 \\
\text { Cl.90 }(0.572,0.723)\end{array}$ & $\begin{array}{c}0.754 \\
\text { Cl.90 }(0.682,0.831)\end{array}$ & $\begin{array}{c}0.746 \\
\text { Cl.90 }(0.684,0.811)\end{array}$ & $\begin{array}{c}0.652 \\
\text { Cl.90 }(0.583,0.712)\end{array}$ & & \\
\hline SQ & $\begin{array}{c}0.769 \\
\text { Cl.90 }(0.704,0.822)\end{array}$ & $\begin{array}{c}0.776 \\
\text { Cl.90 }(0.709,0.837)\end{array}$ & $\begin{array}{c}0.874 \\
\text { Cl.90 }(0.820,0.922)\end{array}$ & $\begin{array}{c}0.610 \\
\text { Cl.90 }(0.534,0.676)\end{array}$ & $\begin{array}{c}0.719 \\
\text { Cl.90 }(0.653,0.783)\end{array}$ & \\
\hline
\end{tabular}

Note: SQ: AT: attitude; CQ: course quality; IQ: information quality; SRL: self-regulated learning; SRQ: service quality; system quality.

The findings of the analysis revealed that there is no value of 1 for the confidence interval of the factors and all values passed the HTMT value of 0.90 tests. This result therefore showed no discriminant validity issues.

\section{Analysis of the Structural Model}

The purpose of this analysis is to confirm or reject the proposed hypotheses. Hair, Anderson, Tatham \& Black (1998) noted that the structural model must involve set of relationships between factors of the hypothesized model. The structural model was evaluated according to the following criteria:

\section{Coefficient of Determination $\left(\mathbf{R}^{2}\right)$ and Predictive Relevance $\left(\mathbf{Q}^{2}\right)$}

The R-square value (R2) indicates the amount of variance corresponding to the dependent variables while the quality of the structural model is evaluated using (Q2) to examine the predictive relevance for the structural model (Tenenhaus, Vinzi, Chatelin, \& Lauro, 2005). Table 3 displays the values of R2 and Q2. 
Table 3. The values of $\mathrm{R} 2$ and $\mathrm{Q} 2$

\begin{tabular}{llllll}
\hline Construct & Relationships & $\mathrm{R}^{2}$ & Result $\left(\mathrm{R}^{2}\right)$ & $\mathrm{Q}^{2}$ & Result $\left(\mathrm{Q}^{2}\right)$ \\
\hline SRL & Attitude -> SRL & 0.563 & Moderate & 0.220 & Medium effect \\
& CourseQ -> SRL & & & & \\
& InfoQ -> SRL & & & & \\
& ServiceQ -> SRL & & & & \\
& SystemQ -> SRL & & & & \\
&
\end{tabular}

According to Table 3 the R2 value is 0.563 , meaning that all five factors (system quality, information quality, service quality, attitude, and course quality) explain $56.3 \%$ of the variance in self-regulated learning. Since the value of $\mathrm{R} 2=0.563$ was between 0.67 and 0.33. a moderate model is suggested (Chin, 1998).

The Q2 analysis applies to the endogenous constructs that represent reflective measurement (Hair et al., 2014). Hair et al. (2014) noted that a Q2 value greater than zero showed that the model has sufficient predictive relevance for the endogenous construct. Table (3) showed that the model has adequate predictive relevance because the $\mathrm{Q} 2$ values for $\mathrm{SRL}(\mathrm{Q} 2=0.220)>0$ and also displayed medium predictive relevance where SRL $(0.220>0.15)$ (Hair et al., 2014).

\section{Path Coefficients}

Path coefficients indicate the strength of a relationship between two variables in the structural model (Cohen, 1988). In this section, a Bootstrapping technique with 5,000 resamples was used to obtain a resulting beta ( $\beta$ ) value and t-values and to evaluate the significance of the hypotheses of the study as recommended by Chin, Marcolin, and Newsted (2003). Table 4 displays the bootstrapping results.

Table 4. Bootstrapping result and hypotheses testing

\begin{tabular}{llllllc}
\hline Hypotheses & Relationship & Std Beta & Std Error & t-value & p-value & Supported \\
\hline H1 & SystemQ -> SRL & -0.094 & 0.054 & 1.751 & 0.081 & No \\
H2 & InfoQ -> SRL & 0.078 & 0.050 & 1.578 & 0.115 & No \\
H3 & ServiceQ -> SRL & 0.168 & 0.044 & $3.842^{* *}$ & 000 & Yes \\
H4 & Attitude - S SRL & 0.328 & 0.047 & $7.001^{* *}$ & 000 & Yes \\
H5 & CourseQ -> SRL & 0.205 & 0.048 & $4.305^{* *}$ & 000 & Yes \\
\hline
\end{tabular}

Note. (t-values $>1.645^{*}$ where $\left.p<0.05\right)$, (t-values $>2.33^{* *}$ where $\left.p<0.01\right)$

Referring to Table 4 , the predictors of self-regulated learning: service quality ( $\beta=0.168)$, attitude $(\beta=$ $0.328)$, and course quality ( $\beta=0.205)$ were all significantly associated with $S R L(p<0.01)$, so H3, H4, H5 were supported. System quality $(\beta=-0.094)$ and information quality $(\beta=0.078)$ were not significant $(p$ $>0.05)$, so $\mathrm{H} 1$ and $\mathrm{H} 2$ were not supported.

\section{Effect Sizes (f 2)}

Effect size ( $\mathrm{f} 2$ ) is used to assess a change in the $\mathrm{R} 2$ when a particular factor is removed from the model. The cutoff values of effect size are: 0.02 small effect, 0.15 medium effect, and 0.35 large effect (Cohen, 1988; Henseler et al., 2009). The results for $\mathrm{f} 2$ are shown in Table 5. 
Table 5. Results of the $\mathrm{f} 2$ effect sizes

\begin{tabular}{llll}
\hline Hypotheses & Relationship & Effect Size $\left(f^{2}\right)$ & Effect Size \\
\hline H1 & SystemQ - SRL & 0.007 & No effect \\
H2 & InfoQ - SRL & 0.005 & No effect \\
H3 & ServiceQ - SRL & 0.024 & Small \\
H4 & Attitude -> SRL & 0.080 & Small \\
H5 & CourseQ - SRL & 0.040 & Small \\
\hline
\end{tabular}

With reference to Table 5, the effect sizes of $\mathrm{H} 3$ were: Service quality $\rightarrow$ SRL (f $2=0.024$ ), H4: Attitude $\rightarrow>$ SRL (f $2=0.080)$, and H5: Course quality $\rightarrow$ SRL $(f 2=0.040)$, all relationships exhibited small effect sizes. However, the effect sizes for H1: (System quality -> SRL), and H2: (Information quality Q -> SRL) had no effect sizes.

In summary, the results for the research model used showed that all factors satisfied the criteria of both the measurement and the structural model, so the proposed model is reliable and demonstrates adequate validity.

\section{DISCUSSION}

\section{The Relationship between System Quality and Self-Regulated Learning in MOOC}

Contrary to other researchers (e.g. Liaw \& Huang, 2013; Zhao, 2016), the result of testing (H1) showed that the influence of system quality on SRL was not supported, indicating that the quality of system features such as ease of use, ease in learning, user expectation of the system, system features, and integration does not influence students' SRL skills.

A possible explanation may be related to students' limited experiences with MOOC, since it is a relatively new field in Malaysia context (Nordin, Norman, \& Embi, 2015). Analyses of demographic data indicated that $41.3 \%$ of the respondents were new to the MOOC environment compared to other e-learning systems. Its features and the way it is conducted may have seemed quite complicated to novice MOOC students, and as novice users they might have experienced problems in navigating the content, activities, and assessments in MOOC.

It therefore seems that not all MOOC students may have the skills necessary to use all MOOC features and participants may also have had confidence issues in using this new technology. Since students new to MOOC tend have obstacles in management of MOOC resources (Kop, 2011), it is suggested that MOOC lectures should provide university training for students to help them acquire the essential skills they need during the MOOC learning and teaching processes.

\section{The Relationship between Information Quality and Self-Regulated Learning in MOOC}

The findings of the study concluded that the hypothesis regarding influence of information quality on SRL (H2) was not supported, and result from testing the hypothesis indicated that more availability and understandability of MOOC information would not increase the level of students' self-regulated learning skills in MOOC. The result of this hypothesis testing was not consistent with some other studies conducted in the e-learning system field (e.g. Liaw \& Huang, 2013; Zhao, 2016).

One possible justification for the non-significant result of this hypothesis is that students have had problems dealing with the volume of information delivered to them via MOOC. This information includes course content, resources, materials, learning activities, and assessments. If these large bundles of information were not well designed, students may become overloaded with information and be unsure as to which should be prioritized.

Rai and Chunrao (2016) provide an example describing the amount of homework required for a MOOC course entitled Introduction to Computing with Java course offered on edX by Hong Kong University of Science and Technology. The course included 6 lab exercises, 26 problem sets, a final project, and a final exam. The feedback from students indicated that the collective course content and activities were too much for them and overburdened them as MOOC learners. 
Consequently, to increase students' self-regulation toward learning via MOOC, it is important for instructors to provide support in terms of guidance and help in navigating the learning content, activities and assessments (Lee \& Lee, 2008). It also is best to deliver highly relevant information to the students and align it with the learning objectives of the course to enhance their ability to organize and regulate their learning processes in MOOC.

\section{The Relationship between Service Quality and Self-Regulated Learning in MOOC}

The results of this study showed that the influence of service quality on SRL (H3) is supported. This indicated that MOOC service quality, including quality of both instructor support and institutional support, can affect students' SRL skills and improve their effectiveness in MOOC participation and their ultimate success in MOOC learning. For example, the reliability of the MOOC system with respect to answering students' enquiries, and the ability of MOOC in delivering lectures, materials, and feedback to students within a reasonable timeframe, can enhance the students' SRL skills and improve their learning using a MOOC system.

Since several researchers (e.g. Liaw \& Huang, 2013; Zhao, 2016) shared similar findings, it is recommended that instructor and institutional support must be considered as key factors for improving self-regulated learning among MOOC students.

\section{The Relationship between Attitude and Self-Regulated Learning in MOOC}

The findings of the study concluded that the influence of attitude on SRL (H4) was significant. In other words, a positive student attitude towards MOOC contributes to an improvement in SRL skills, thereby impacting learning success.

A possible explanation for this finding might be that the positive impression of students toward MOOC activities, such as feeling confidence, enjoyment, and interest in using MOOC, may lead to improvements in their self-regulated learning skills. These skills would include the ability to independently organize and plan the learning process, to set learning goals, and to identify effective ways to learn.

The results from hypothesis (H4) are consistent with studies conducted by Kramarski and Gutman (2006), and Zimmerman and Schunk (2001) who found that student attitudes influence their self-regulated learning in e-learning. Researchers such as Presley and Presley (2009), and Hammoud (2010) indicated that student attitudes contribute significantly to successful e-learning implementation.

\section{The Relationship between Course Quality and Self-Regulated Learning in MOOC}

Testing hypothesis $\mathrm{H} 5$ showed that the influence of course quality on SRL was significant. This finding provided evidence that aspects of quality content such as design, appropriateness of outputs, and ease of understanding of course materials played important roles in supporting SRL skills in a MOOC learning environment.

The significant relationship between course quality and SRL indicated that success in MOOC depends on high-quality course design, its content, and ease of understanding the learning materials. The finding of this hypothesis is supported by studies such as those by Hassanzadeh et al. (2012); Owens and Price (2010); and Sun, Tasi, Finger, and Chen (2008), who indicated that content quality factor has a direct impact on the success of learning in online environments.

The quality of course content is one of the most crucial elements motivating learners around the world to join and engage in MOOC platforms (Yousef, Chatti, Schroeder, \& Wosnitza, 2014). An excellent course design will contribute to make students more independent in organizing and planning their learning process and encouraging them to set learning goals, identify effective ways to learn, and achieve success in MOOC learning. Lin, Lin, and Hung (2015) argue that the perceptions of learners toward the quality and richness of MOOC course content have a significant influence on accepting the knowledge.

It is therefore suggested that MOOC developers and instructors should ensure that MOOC materials are easy to understand, and that only high-quality content is to be presented in high-quality format to establish real opportunities for students to become more responsible learners via MOOC. 


\section{CONCLUSION}

Several studies have highlighted the vital role of self-regulation skills in MOOC (Hood et al., 2015; Kizilcec et al., 2016; Littlejohn et al., 2016; Onah \& Sinclair, 2017). Since learners with a higher degree of selfregulated learning are more likely to succeed, developing self-regulated learning abilities in MOOC is a key factor in achieving successful learning in a MOOC environment. While online courses have been found to be favorably regarded by students who have acquired self-regulated learning skills (You \& Kang, 2014), research studies related to supporting students to enhance their self-regulated learning skills while learning in a MOOC environment are quite limited. This study, therefore, contributed to closing the gap in the current literature by examining six main factors that influence students' self-regulated learning skills in MOOC environments, and the findings add insight on how to create a successful MOOC environment to support self-regulated learning.

Based on the study's results, the empirical findings indicate that improvement of service quality, attitude, and course quality is very important for promoting self-regulated learning in MOOC environments. In other words, creating self-regulated MOOC environments should build effective interactive learning environments in which these three factors would be carefully considered.

The results of this study are supported by several MOOC study findings that showed the effectiveness of SRL on MOOC (Magen-Nagar \& Cohen, 2016). For instance, the result of study by Littlejohn et al. (2016) found that MOOC learners who reported high-level of SRL skills were apt to have more flexibility in their approach to learning and determined their learning paths by themselves.

In sum, this study has investigated the influence of five factors - system quality, information quality, service quality, student attitude and course quality - on students' self-regulated learning skills in a MOOC environment. Thus, this paper extends existing research on SRL to a newer form of learning - MOOC. Future study is hoped to explore the influence of other factors especially psychological aspect on students' SRL in MOOC. It is also suggested that future study to expand the scope of such research into cross-country and culture comparison to better understand how best to support learning in a MOOC environment.

\section{BIODATA and CONTACT ADDRESSES of AUTHORS}

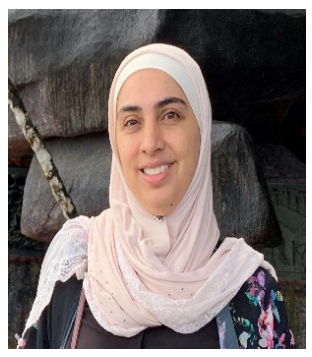

Nour Awni ALBELBISI, is currently a Ph.D. student at the University of Malaya, Malaysia. She holds a Master degree in Instructional Technology at the University of Malaya. Her current research interests are online homework, Massive Open Online Courses (MOOCs), and online learning. She has published high impact journal articles including articles indexed in ESCI, Scopus and book chapters.

\section{Nour Awni ALBELBISI}

Address: Department of Curriculum and Instructional Technology, Faculty of Education

University of Malaya, 50603 Kuala Lumpur, MALAYSIA

Phone: +601161870700

E-mail: noorbelbisi@gmail.com 


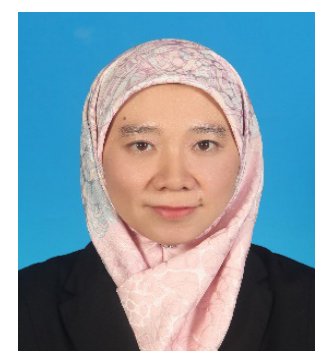

Dr. Farrah Dina YUSOP, is an Assistant Professor of Instructional Design and Technology at University of Malaya. She holds a PhD in two fields: Curriculum and Instructional Technology (CIT) and Human Computer Interaction (HCI) from Iowa State University (ISU), USA in 2010. Her academic interests are professional development in higher education and application on technologies for learning improvement, including Web 2.0, social media, educational games and mobile learning. She has published more than 20 high impact journal articles including articles indexed in Tier 1 SSCI, Scopus and ERA, books and book chapters. Dr. Yusop also recipient of several prestigious national and international awards including Outstanding Woman in Humanities and Social Sciences Award 2018, AECT Outstanding Journal Article Award 2015 (USA) and Malaysian Minister of Education Special Award: Curriculum design and innovative delivery (AKRI) 2018, among others.

Farrah Dina YUSOP

Address: Department of Curriculum and Instructional Technology, Faculty of Education

University of Malaya, 50603 Kuala Lumpur, Malaysia

Phone: +603-79677816

E-mail: farah@um.edu.my

\section{REFERENCES}

Alraimi, K. M., Zo, H., \& Ciganek, A. P. (2015). Understanding the MOOCs continuance: The role of openness and reputation. Computers \& Education, 80, 28-38.

Alsabawy, A. Y., Cater-Steel, A., \& Soar, J. (2012). A model to measure e-learning systems success. Measuring Organizational Information Systems Success: New Technologies and Practices, Business Science Reference, Hershey, PA, 293-317.

Alsabawy, A. Y., Cater-Steel, A., and Soar, J. (2011). Measuring e-learning system success (Research in progress). In Proceedings of the 15th Pacific Asia Conference on Information Systems (PACIS 2011, July) (pp. 1-15). Queensland University of Technology.

Authors (2018). Mapping the Factors Influencing Success of Massive Open Online Courses (MOOC) in Higher Education. Eurasia Journal of Mathematics, Science and Technology Education, 14(7), 29953012.

Auvinen, T. (2015). Educational Technologies for Supporting Self-Regulated Learning in Online Learning Environments.

Barnard-Brak, L., Paton, V. O., \& Lan, W. Y. (2010). Profiles in self-regulated learning in the online learning environment. The International Review of Research in Open and Distributed Learning, 11(1), 61-80.

Broadbent, J., \& Poon, W. L. (2015). Self-regulated learning strategies \& academic achievement in online higher education learning environments: A systematic review. The Internet and Higher Education, 27, 1-13. http://dx.doi.org/10.1016/j.iheduc.2015.04.007

Chin, W. W., Marcolin, B., \& Newsted, P. (2003). A partial least squares latent variable modeling approach for measuring interaction effects: Results from a Monte Carlo simulation study and an electronicmail emotion/adoption study. Information Systems Research, 14(2), 189-217.

Cho, M. H., \& Kim, B. J. (2013). Students' self-regulation for interaction with others in online learning environments. The Internet and Higher Education, 17, 69-75.

Cho, M., \& Shen, D. (2013). Self-regulation in online learning. Distance Education, 34(3), 290-301. http:// dx.doi.org/10.1080/01587919.2013.835770

Cohen, J. (1988). Statistical power analysis for the Behavioral Sciences. Mahwah, NJ: Erlbaum.

Daniel, J., \& Uvalic-Trumbic, S. (2013). Turbulent times in tertiary education: Lessons for Bangladesh. Paper presented at the International Conference on Tertiary Education: Realities and Challenges, Daffodil University, Bangladesh. 
Davis, D. J., Chen, G., Jivet, I., Hauff, C., \& Houben, G. (2016). Encouraging metacognition and selfregulation in MOOCs through increased learner feedback. CEUR Workshop Proceedings, 1596, 17-22. Retrieved from http://ceur-ws.org/Vol-1596/paper3.pdf

de Waard, I., Gallagher, M. S., Zelezny-Green, R., Czerniewicz, L., Downes, S., Kukulska-Hulme, A., \& Willems, J. (2014). Challenges for conceptualising EU MOOC for vulnerable learner groups. Proceedings of the European MOOC Stakeholder Summit 2014, 33-42.

DeLone, W. H., \& McLean, E. R. (2003). The DeLone and McLean model of information systems success: A ten-year update. Journal of Management Information Systems, 19(4), 9-30.

Freeze, R. D., Alshare, K. A., Lane, P. L., \& Wen, H. J. (2010). IS Success Model in ELearning context based on students' perceptions. Journal of Information Systems Education, 21(2), 173-184.

Gold, A. H., Malhotra, A., \& Segars, A. H. (2001). Knowledge management: an organizational capabilities perspective. Journal of Management Information Systems, 18(1), 185-214.

Hair, J. F., Black, W. C., Babin, B., Anderson, R. E., \& Ronald, L. T. (2006). Multivariate data analysis (5th ed.). Englewood Cliffs, NJ: Prentice Hall.

Hair, J. F., Hult, G. T. M., Ringle, C. M., \& Sarstedt, M. (2014). A primer on partial least squares structural equation modeling (PLS-SEM). Thousand Oaks, CA: SAGE.

Hair, J. F., Ringle, C. M., \& Sarstedt, M. (2011). PLS-SEM: Indeed a silver bullet. Journal of Marketing theory and Practice, 19(2), 139-152.

Hair, J.F., Anderson, R.E. , Tatham, R.L. , \& Black, W.C. . (1998). Multivariate data analysis (5th ed.). New Jersey: Prentice Hall.

Hair, J.F., Black, W.C. , Babin, B., \& Anderson, R.E. . (2010). Multivariate data analysis (7th ed.). New Jersey: Prentice Hall.

Hammoud, L. (2010). Factors affecting students' attitude and performance when using a web-enhanced learning environment (Doctoral dissertation, Brunel University, School of Information Systems, Computing and Mathematics PhD Theses). Retrieved from http://bura.brunel.ac.uk/bitstream/2438/4622/1/ FulltextThesis.pdf

Hassanzadeh, A., Kanaani, F., \& Elahi, S. (2012). A model for measuring e-learning systems success in universities. Expert Systems with Applications, 39(12), 10959-10966.

Henseler, J., Ringle, C. M., \& Sarstedt, M. (2015). A new criterion for assessing discriminant validity in variance-based structural equation modeling. Journal of the academy of marketing science, 43(1), 115-135. doi:10.1007/s11747-014-0403-8.

Henseler, J., Ringle, C. M., \& Sinkovics, R. R. (2009). The use of partial least squares path modeling in international marketing. In New challenges to international marketing (pp. 277-319). Emerald Group Publishing Limited.

Hew, K. F., \& Cheung, W. S. (2014). Students' and instructors' use of massive open online courses (MOOCs): Motivations and challenges. Educational Research Review, 12, 45-58. doi: 10.1016/j. edurev.2014.05.001

Hood, N., Littlejohn, A., \& Milligan, C. (2015). Context counts: How learners' contexts influence learning in a MOOC. Computers \& Education, 91, 83-91.

Hulland, J. (1999). Use of partial least squares (PLS) in strategic management research: a review of four recent studies. Strategic Management Journal, 20(2), 195-204.

Kizilcec, R. F., \& Halawa, S. (2015, March). Attrition and achievement gaps in online learning. Paper presented at Learning@Scale 2015, Vancouver. http://dx.doi.org/10.1145/2724660.2724680

Kizilcec, R. F., Pérez-Sanagustín, M., \& Maldonado, J. J. (2016, April). Recommending self-regulated learning strategies does not improve performance in a MOOC. Paper presented at Learning @ Scale 2016, Edinburgh. http://dx.doi.org/10.1145/2876034.2893378 
Kizilcec, R. F., Pérez-Sanagustín, M., \& Maldonado, J. J. (2017). Self-regulated learning strategies predict learner behavior and goal attainment in Massive Open Online Courses. Computers \& Education, 104, 18-33. http://dx.doi.org/10.1016/j.compedu.2016.10.001

Kline, R. B. (2011). Principles and practice of structural equation modeling (3rd ed.). New York, NY: Guilford Press.

Kop, R. (2011). The challenges to connectivist learning on open online networks: Learning experiences during a massive open online course. The International Review of Research in Open and Distributed Learning, 12(3), 19-38.

Kramarski, B., \& Gutman, M. (2006). How can self-regulated learning be supported in mathematical Elearning environments?. Journal of Computer Assisted Learning, 22(1), 24-33.

Lee, J.K., \& Lee, W.K. (2008). The relationship of e-Learner's self-regulatory efficacy and perception of e-Learning environmental quality. Computers in Human Behaviour, 24(1), 32-47.

Lee, Y., Choi, J., \& Kim, T. (2012). Discriminating factors between completers of and dropouts from online learning courses. British Journal of Educational Technology, 44(2), 328-337. http://dx.doi. org $/ 10.1111 /$ j. $1467-8535.2012 .01306 . x$

Liaw, S. S., \& Huang, H. M. (2013). Perceived satisfaction, perceived usefulness and interactive learning environments as predictors to self-regulation in e-learning environments. Computers \& Education, 60(1), 14-24.

Lin, Y.-L., Lin, H.-W., \& Hung, T.-T. (2015). Value hierarchy for massive open online courses. Computers in Human Behaviour, 53, 408-418.

Littlejohn, A., \& Milligan, C. (2015). Designing MOOCs for professional learners: Tools and patterns to encourage self-regulated learning. eLearning Papers, 42.

Littlejohn, A., Hood, N., Milligan, C., \& Mustain, P. (2016). Learning in MOOCs: Motivations and selfregulated learning in MOOCs. The Internet and Higher Education, 29, 40-48.

Magen-Nagar, N., \& Cohen, L. (2016). Learning strategies as a mediator for motivation and a sense of achievement among students who study in MOOCs. Education and Information Technologies, 1-20. http://dx.doi.org/10.1007/s10639-016-9492-y

Mazoue, J. G. (2014). The MOOC model: Challenging traditional education. Educause Review.

Milligan, C., Littlejohn, A., \& Margaryan, A. (2013). Patterns of engagement in connectivist MOOCs. MERLOT Journal of Online Learning and Teaching, 9(2), 149-159.

Nawrot, I., \& Doucet, A. (2014, April). Building engagement for MOOC students: Introducing support for time management on online learning platforms. Paper presented at the 23rd International World Wide Web Conference, Seoul, South Korea. http://dx.doi.org/10.1145/2567948.2580054

Nordin, N., Norman, H., \& Embi, M. A. (2015). Technology acceptance of massive open online courses in Malaysia. Malaysian Journal of Distance Education, 17(2), 1-16.

Onah, D. F. O., \& Sinclair, J. E. (2017). Assessing self-regulation of learning dimensions in a stand-alone MOOC platform. International Journal of Engineering Pedagogy (iJEP), 7(2), 4-21.

Owens, J. D., \& Price, L. (2010). Is e-learning replacing the traditional lecture? Education and Training Journal, 52(2), pp. 128-139.

Ozkan, S., Koseler, R., \& Baykal, N. (2009). Evaluating learning management systems: Adoption of hexagonal e-Learning assessment model in higher education. Transforming Government: People, Process and Policy, 3(2), 111-130.

Parr, C. (2013). MOOC completion rates 'below 7\%,'. Times higher education, 9. Retrieved from http:// www.timeshighereducation.co.uk/news/moocs-completion-ratesbelow- 7/2003710

Presley, A., \& Presley, T. (2009). Factors influencing student acceptance and use of academic portals. Journal of Computing in Higher Education, 21(3), pp.167-182. Retrieved from www.springerlink.com/ index/e575145287667515.pdf 
Rai, L., \& Chunrao, D. (2016). Influencing factors of success and failure in MOOC and general analysis of learner behavior. International Journal of Information and Education Technology, 6(4), 262.

Rhema, A., \& Miliszewska, I. (2014). Analysis of student attitudes towards e-learning: The case of engineering students in Libya. Issues in Informing Science and Information Technology, 11, 169-190.

Ringle, C. M., Wende, S., \& Becker, J-M. (2015). SmartPLS 3. Hamburg, Germany: SmartPLS. Retrieved from http://www.smartpls.com

Samarasinghe, S. M. (2012). e-Learning systems success in an organisational context: a thesis presented in partial fulfilment of the requirements for the degree of Doctor of Philosophy in Management Information Systems at Massey University, Palmerston North, New Zealand (Doctoral dissertation, Massey University). Retrieved from http://hdl.handle.net/10179/4726

Sun, P., Tasi, R. J., Finger, G., \& Chen, Y. (2008). What drives a successful e- learning? An empirical investigation of the critical factors influencing learner satisfaction. Computers \& Education, 50(4), 1183-1202.

Tella, A. (2011). Reliability and factor analysis of a blackboard course management system success: A scale development and validation in an educational context. Journal of Information Technology Education: Research, 10, 55-80.

Tenenhaus, M., Vinzi, V. E., Chatelin, Y. M., \& Lauro, C. (2005). PLS path modeling. Computational Statistics \& Data Analysis, 48(1), 159-205.

Terras, M. M., \& Ramsay, J. (2015). Massive open online courses (MOOCs): Insights and challenges from a psychological perspective. British Journal of Educational Technology, 46(3), 472-487. http://dx.doi. org/10.1111/bjet.12274

Wang, H. C., \& Chiu, Y. F. (2011). Assessing e-learning 2.0 system success. Computers \& Education, 57(2), 1790-1800.

You, J.W., \& Kang, M. (2014). The role of academic emotions in the relationship between perceived academic control and self-regulated learning in online learning. Compute Educ. 77, 125-133. doi:10.1016/j. compedu.2014.04.018

Yousef, A. M. F., Chatti, M. A., Schroeder, U., \& Wosnitza, M. (2014). What drives a successful MOOC? An empirical examination of criteria to assure design quality of MOOCs. In Advanced Learning Technologies (ICALT), 2014 IEEE 14th International Conference on (pp. 44-48). IEEE.

Zhao, H. (2016). Factors influencing self-regulation in e-learning 2.0: Confirmatory factor model. Canadian Journal of Learning and Technology, 42(2), n2.

Zimmerman, B. J. (2015). Self-regulated learning: theories, measures, and outcomes.

Zimmerman, B.J. \& Schunk, D.H. (2001). Self-regulated Learning and Academic Achievement: Theoretical perspectives. Mahwah, N.J.: Lawrence Erlbaum. 